\title{
MOLECULAR DETECTION OF ASTROVIRUS USING REVERSE TRANSCRIPTASE QUANTITATIVE POLYMERASE CHAIN REACTION TECHNIQUE
}

\author{
H. Y. Fadhil ${ }^{1} *$ \\ Assist.Prof.
}

\section{J. Abed Al-kareim ${ }^{1}$} Assist. Lecture

${ }^{1}$ Dept. Biol. Coll. Sci. University of Baghdad.

I. M. Aufi ${ }^{2}$

Chief Biologist
F. G. Alhamdani ${ }^{2}$

Consultant Doctor

${ }^{2}$ Dept. Virol. National Central Public Health Lab. Ministry of Health.

* Corresponding Author E-mail: hulayounis@yahoo.com

\section{ABSTRACT}

This study was aimed to highlight the importance of the melt curve-quantitative reverse transcriptase PCR (RT-qPCR) analysis in the detection of astrovirus (AstV) from both negative and positive rotavirus and enterovirus (EVs) samples, and the effectiveness of the AstV infection on the vaccine immunogenicity in the vaccinated infected children. By RT-qPCR based Sybre green associatedmelting curve assay, stool samples of 49 enterovirus suspected patients and of 39 rotavirus suspected patients were tested for AstV. Results of EVs group showed a $29(59.2 \%)$ positive AstV contributed to $26(\mathbf{8 9 . 5 \% )}$ co-infection with Evs and $3(\mathbf{1 0 . 3 \%})$ as a single infection in negative samples for Evs. Furthermore, AstV co-infection percentage is higher than the single infection. Moreover, the percentage of the Astrovirus among the vaccinated AFP-suspected cases was 53\%, while the percentage of these viruses among the unvaccinated was 100\%. Thus, MamAstrovirus- 1 MK948878 is the first local isolate recorded in the Genbank. In conclusion, the RT-qPCR based on SYBR Green showed the rapid and efficient detection of AstV with few copies number. This allow to be used for the diagnosis of AstV along with other gastroenteritis viruses in a multiplex assay to reduce processing time.

Keywords: rotavirus, Real-Time RT-PCR, Enterovirus, phylogenetic tree, sequences.

فاضل وآخرون مجلة العلوم الزراعية العراقية -2020 :200-191:51: التحري الجزيئي للفايروس النجي باستخدام تقنية تفاعل سلسلة البلمرة عكس الاستنساح اللحظي

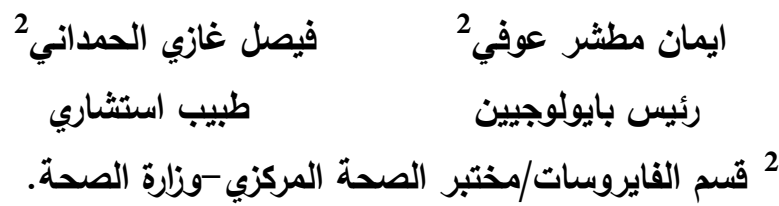

$$
\begin{aligned}
& \text { ميس جاسم عبد الكريم } 1 \\
& 1 \text { حُلا يونس فاضل } \\
& \text { مدرس مساعد } \\
& \text { أستاذ مساعد } \\
& \text { 1قسم علوم الحياة/كلية العلوم - جامعة بغداد. }
\end{aligned}
$$

المستخلص

تهدف الاراسة إلى تسليط الضوء على أهمية أختبار تفاعل سلسلة البلمرة عكس الاستتساح اللحظي (RT-qPCR) لمنحنى الأويان في الكشف عن الفيروس النجمي (AstV) في كل من العينات الموجبة والسالبة للفيروس العجلي الدوار(rotavirus) والفايروسات المعوية (enterovirus-EV)، وتاثير اصابات لثى الخاصية المستضدية المناعية للقاح لاى الأطفال الملقحين. بالاعتماد على منحنى الانصهار الأخضر د RT-qPCR ، اختبرت عينات البراز لاصابات AstV من 49 مريضاً مصابين بالقيروسات المعوية و 39 من مرضى مصابين بالفيروس الدوار ـ أظهرت نتائج مجموعة EVs أن 29 (59.2 \% ) موجب لاصابات AstV توزعت 26 (89.5 \%

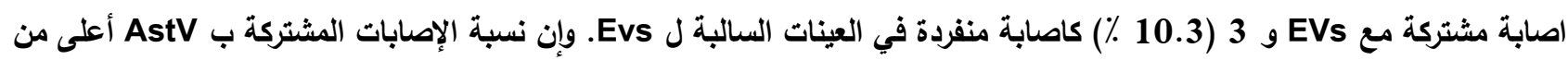
الاصابات المنفردة .فضلاً عن ذلك، شكلت النسبة المئوية للفيروسات النجمية بين الحالات الملقحين والمشتبه في اصاباتهم بالثلل الرخوي الحاد هي 53 \%، في حين كانت النسبة 100 \% في غير الملقين • وإن MamAstrovirus- 1 MK948878 هي أول عزلة محلية سجلت في بنك الجينات العالمي. استنتج هذه الدراسة بان اختبار RT-qPCR المعتمد على السايبر الخضراء سريع وفعال بالكثف عن في في في AstV مع عدد قليل من النسخ .ويسمح هذا باستخدامه لتشخيص AstV مع فيروسات اخرى لالتهاب المعدة والأمعاء باستخدام اختبار

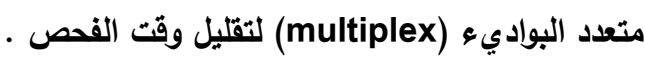

الكلمات المفتاحية: الفايروس العجلي الدوار، تفاعل سلسلة البلمرة العكسي اللحظي، الفايروسات المعوية، الشجرة الجينية, تتابع القواعد 


\section{INTRODUCTION}

Worldwide, acute gastroenteritis is now one of the most common infections among humankinds (36), which is characterized by vomiting, abdominal pain, nausea, fever and diarrhea that represents the most common symptoms and responsible for many childhood morbidity and mortality, especially in developing countries (35). Although rotavirus, norovirus and adenovirus have been documented as causative agents for gastroenteritis, presently, viruses like astroviruses are also vital, has been linked to frequent cases of acute gastroenteritis in young children, old people and immunocompromised individuals and supposed to represent up to $20 \%$ of sporadic viral diarrhea cases and 0.5 $15 \%$ of total outbreaks (24), but it has been the topic for limited studies (10). astroviruses, are non-enveloped single-stranded positive-sense RNA viruses, belong to the family astroviridae which were firstly discovered in 1975 by electron microscopy in stool samples from children with acute gastroenteritis (9). Its genome divided into three open reading frames (ORFs): ORF1a (non-structural protein), ORF1b (non-structural protein) and ORF2 (capsid protein), a $3^{\prime}$ UTR and a polyA tail (21). Astroviruses classified into two genera: mammalian viruses (Mamastroviruses (MAstVs), 19 species and avian viruses (Avastroviruses (AAstVs), three species recognized both by (ICTV) (15). However, astroviruse infect mostly the pediatric population (28). The age of affected children with classic HAstV is highly variable, fluctuating from neonates to above 5 years, however, astroviral infection is more mutual among those younger than two (12). The usual circulation of astrovirus is more frequent in temperate regions with a better stability in the cold weather period, however HAstVs endure to circulate all over the year, and infections do happen in summer too (1). Other viral gastroenteritis agents such as rotaviruses and noroviruses, but not adenoviruses, present a parallel seasonal outline (16). In Iraq, there are several previous papers have studied astroviruses and its association with gastroenteritis in children by two molecular $(27,33)$ and immunological methods $(6,8,19$, 7). It's good to know, that there are no previous local studies isolated the virus from vaccinated children with oral Polio vaccine for the enterovirus study group and with Rota vaccine for the rotavirus study group. Moreover, this is the first study relied on real time reverse transcriptase polymerase chain (RT-qPCR) reaction associated with melt curve analysis in detection of astrovirus. As well, the original stool samples were taken from previously identified samples for rotavirus and enterovirus by ELISA and by tissue culture for enterovirus to increase the accuracy (i.e the specifity and sensitivity) in the diagnosis. Furthermore, there is the no previous Iraqi study typed the astrovirus serotypes by the nucleotide sequence analysis and stated its similarity with other world reference serotypes. So that, this study aimed to highlight the importance of the melt curvequantitative reverse transcriptase PCR (RTqPCR) analysis in the detection of astrovirus (AstV) from both negative and positive rotavirus and enterovirus (EVs) samples, and the effectiveness of the AstV infection on the vaccine immunogenicity in the vaccinated infected children.

\section{MATERIALS AND METHODS \\ Study population}

From the National Central Public Health Laboratory/ Iraq (CPHL) / National Polio Laboratory, during March to December, 2018. Eighty eight stool samples of patients suffered from gastroenteritis and/ or acute diarrhea were collected with aged 1 to 48 month (47 male and 41 female). Ninety three samples of them were selected from patients suspected with rotavirus and previously tested for this virus by the Enzyme Linked Immunosorbent (ELISA). The second study subjected group was selected from 49 samples from patients infected with Acute Flaccid Paralysis (AFP) and previously tested for Enterovirus (Sabinepolio and non- polio Enterovirus) by tissue culture method.

\section{RNA extraction}

All the 88 original stool samples have been processed for RNA extraction. RNA was taken out according to the producer's directions from all the specimens using the QIAamp Viral RNA Mini kit (Qiagen GmbH, Germany) (3).
Quqntitative
Reverse
Transcriptase Polymerase Chain Reaction (RT-qPCR): By 
GoTaq ${ }^{\circledR}$ one-Step RT-qPCR system protocol, using a nucleic acid stain (typically SYBR green by adding to PCR tube $5 \mu \mathrm{l}$ of the GoTaq qpcr master mix; $2 \mathrm{x}, 0.8 \mu \mathrm{l}$ of each primer and $0.5 \mu$ l of enzyme mix) associated with melting curve analysis (2), with mean $=$ 33.45 for cycle number $(\mathrm{Ct})$ and mean $=73.51$ for Tm in astrovirus positive samples. The RTqPCR, has been done for the detection 88 samples of Astrovirus, by amplifying the open reading frame- $1 b$ by the ORF1b primer (23) as a forward primer (5'CCGAGTAGGATCGAGGGT-' 3 ) and a reverse primer $\left(5^{\prime}\right.$ GCTTCTGATTAAATCAATTTTAA-'3) with a product size $93 \mathrm{nt}$ in this study.

\section{Reverse transcriptase Polymerase Chain} Reaction (RT-PCR).

For further molecular typing to the Astrovirus- positive samples by the nucleotide sequence analysis, the open reading frame $1 \mathrm{~b}$ of the samples extracted RNA has been amplified by the RT-PCR assay by using ORF1b primers, a forward primer (5'GGACTGCAAAGCAGCTTCGTG-'3) and reverse primer $\left(5^{\prime}\right.$ GTGAGCCACCAGCCATCCCT-'3) with a product size 719 base pairs (37). The amplicons were run on agarose gel $1 \%$ and visualized with Transilluminator, using the ladder ranged 100-1000 bp (5).

\section{Sequencing for RT-PCR product}

For ORF1b gene sequencing, the RT-PCR product has been sent to Macrogen Company, USA by using forward primer ORF1b on a genetic analyzer (Applied Biosystems). The homology search was performed using the Basic Local Alignment Search Tool (BLAST) program online using blastn and blastx algorithm which is available at the NCBI online at (http://www.ncbi.nlm.nih.gov). To classify the positive local Astrovirus strains, the phylogenetic tree was performed applying the neighbor-joining method and the genetic distances were calculated according to the maximum composite likelihood model with 100-bootstrap using the MEGA version 6.0 software. A bootstrap value of 70 was used as an indicator of the significance of the clusters.

\section{Statistical analysis}

The statistical analysis system was analyzed by IBM SPSS Statistics version 25. All values were calculated according to the positive results as percentages (\%). Differences between study groups and assays were analyzed by cross-tab and Pearson chi-square $\left(\mathrm{X}^{2}\right)$ test, while the Kruskal-Wallis test applied to check the signs between age groups. A value of $\mathrm{P}<0.05$ was considered statistically significant.

\section{RESULTS AND DISCUSSION Detection of astrovirus by RT- qPCR assay in the enterovirus and rotavirus suspected groups}

Using RT-qPCR based Sybre green associated- melting curve assay (Fig.1), stool samples of 49 EVs suspected patients and of 39 Rotavirus suspected patients were tested for Astrovirus. The out of 49, $37(75.5 \%)$ tissue culture-positive, non-polio enteroviruses (NPEVs) samples, $5(10.2 \%)$ poliovirus and 7 (14.3\%) negative samples. Results of Astrovirus detection with RT-qPCR in EVs group showed a $29(59.2 \%)$ positive sample contributed to $26(89.5 \%)$ co-infection with EVs and $3(10.3 \%)$ as a single infection in negative samples for EVs. Furthermore, Astrovirus co-infection percentage is higher than the single infection of the astrovirus with a significant difference $\left(\mathrm{X}^{2}=18.24, \mathrm{P}<0.01\right)$. For the Rotavirus suspected group, 26 (66.7\%) of 39 samples were positive for Rotavirus immunologically and molecularly. Otherwise, Astrovirus infection showed 17/39 (43.59\%) distributing $11 \quad(64.7 \%)$ samples were constituted the co-infection model of astrovirus with rotavirus. The remaining rotavirus negative samples $(33.3 \%)$ recorded 6 (35.2\%) positive results for astrovirus as a single infection model and there is no significant difference with mixed infection $\left(\mathrm{X}^{2}=1.47 ; \mathrm{P}>0.05\right)$ (Table-1). 
Table 1. The frequency of the astrovirus infections among the rotavirus and EVs suspected groups testing with RT-qPCR assay

\begin{tabular}{|lc|}
\hline \multicolumn{2}{|c|}{ Astrovirus frequency in the EVs- suspected group } \\
\hline & \\
A Single infection (negative) & $3(10.3 \%)$ \\
Astrovirus-Sabine- Polio co-infection (EV) & $4(13.7 \%)$ \\
Astrovirus-NPEVs co-infection (EV) & $22(75.8 \%)$ \\
& $29(100 \%)$ \\
Total & \\
\hline \multicolumn{2}{|c|}{ Astrovirus frequency in the Rotavirus- suspected group } \\
\hline A Single infection & $\mathbf{6}(35.3 \%)$ \\
Astrovirus- Rotavirus co-infection & $11(64.7 \%)$ \\
Total & $17(100 \%)$ \\
\hline
\end{tabular}

It's good to be mentioned that the co- infection model of the astrovirus with enteroviruses was higher than with the rotaviruses while the astovirus- single infection showed the contrary (figure-1). Moreover, the percentage of the astrovirus among the vaccinated AFP suspected cases was $53 \%$, while the percentage of these viruses among the unvaccinated was $100 \%$.

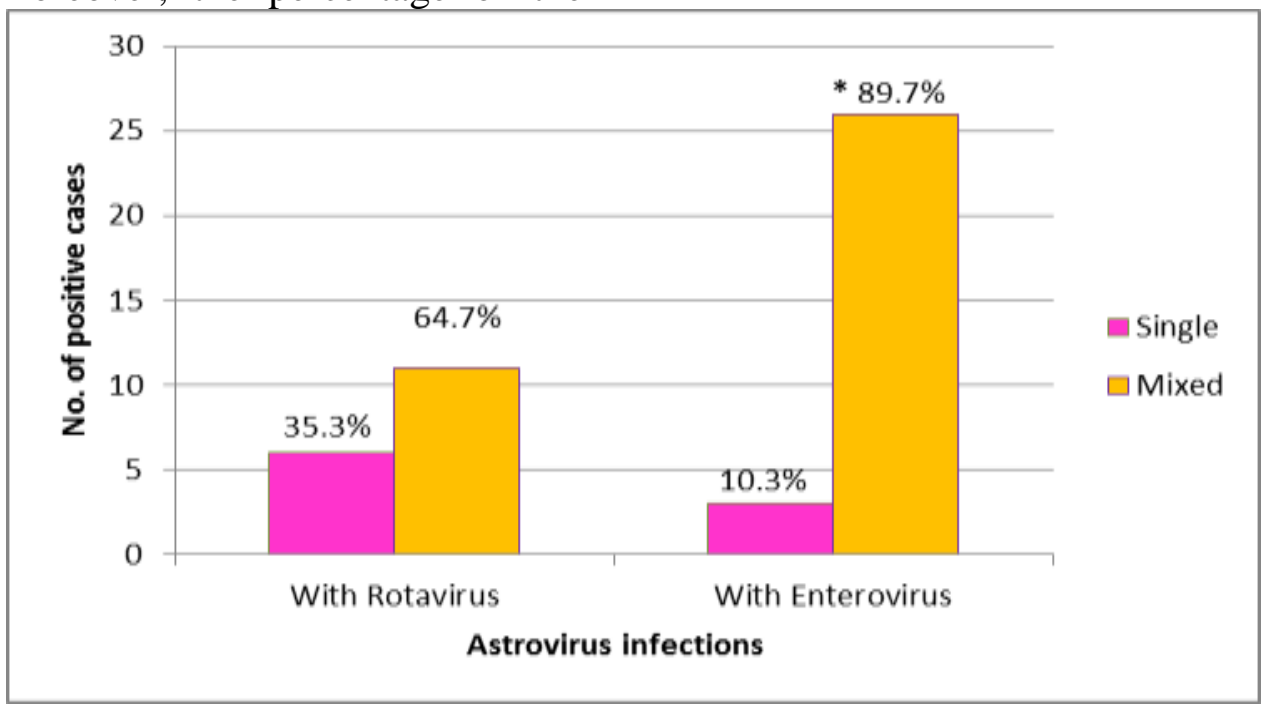

Figure 1. Frequency of astrovirus single and mixed infection tested by Sybre green assay and accompanied with the enteroviruss and rotavirus groups. Asterisk pointed out significance appearance with enteroviruses

To our knowledge, there are no Astrovirus specific probes have been used with RT-qPCR in this study, otherwise, the one step Sybr green RT-qPCR (30) followed by melting curve analysis have introduced a good alternative way in detection of these viruses and this agreed with (29) study about the molecular ways of Astrovirus diagnosis. Sybr green assay has ability to detect sensitive and rapid a few copies numbers (low viral load) by melting curve than Taqman assay more clearly diagnosed with $\mathrm{Ct}$ below $38(31,17)$.

Detection of Astrovirus in the Rotavirus and Enterovirus suspected group using RTPCR: Among the 88 isolates, few isolates have high viral load from co-infection sample with Rotavirus appeared $17 \mathrm{Ct}$ (cycle number) of amplification curve and 76.1 Tm of melting curve in the RT-qPCR (Fig.2) as a positive result for Astrovirus, and 719 base pair when the RT-PCR assay performed. This isolate was further analyzed by the nucleotide sequence analysis in order to type it and examine its evolutionary relationships with other international strains. The remaining astrovirus positive samples were low viral load with $\mathrm{Ct}$ more than 32 in RT-qPCR and less clear in observing the specific band with RT-PCR assay (Fig.3). 


\section{Melt Curve}

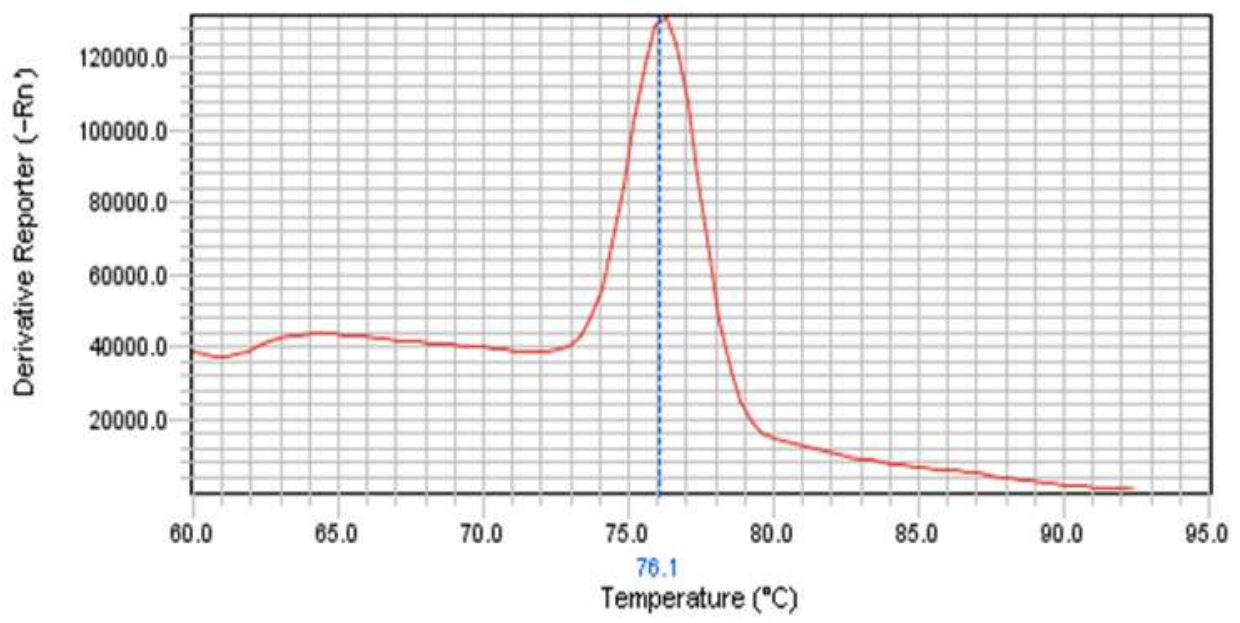

Figure 2. Melting curve of the amplification atrovirus positive sample with high viral load (Ct

\section{7) detection based on Sybre green RT-qPCR assay}

In contrary to other local studies in Iraq, the overall rate of incidences for Astrovirus in this study was $52.2 \%(46 / 88)$ out of both rotavirus and enterovirus study isolates in the gastroenteritis infected patients in both infectious models (single and co-infection). While other studies have shown low singleinfection prevalence for astrovirus. This exemplified with Al-Sadawi et al., study in Alnajaf/ Iraq which recorded 3/200 (10.4\%) chromate-graphic immunoassay- positive Astrovirus results (7), Ali et al., 2016 in Baghdad/ Iraq in which out of the 465 samples analyzed only $10.1 \%$ were immunochromatographic assay positive astrovirus results (6), Mitab, 2013 in Almuthana/ Iraq study which recorded 39/335 (11.6\%) multiplex rRT-PCR technique positive results for Astrovirus (27) and AlShuwaikh, 2016 study in Baghdad/ Iraq along with Hussein, et al., 2018 study in Dyala/ Iraq that gave zero $(0 \%)$ results for Astrovirus by the immunochromatographic assay from 188 and 160 samples with Acute Diarrhea respectively $(8,19)$. The highest incidence rate in this study has matched only with Mitab, 2013 study (6), this may be explained the high accuracy and sensitivity of the RT-qPCR assay in the detection of these viruses and this matched with what mentioned in other previous studies $(14,25)$. In comparison to other global molecular based studies from Italy (11), Germany (20), lebanon (38), Egypt (4) and Iran (26). The prevalence of HAstV in this study is the highest, telling that this virus exists, flowing and contributing expressively to gastroenteritis in different Iraqi provinces. The high incidence of Astrovirus relies on the age of patients, analytical approaches used and the season of isolates assembly in which HAstV infectious rate is more common among those younger than 2 and in temperate regions in the cold weather period beside of using RTqPCR assays that provide high speed, sensitivity and reproducibility and reduction of contamination risk in the diagnostic of HAstVs $(30,26)$. As a result, our findings have corresponded to the previous ideal criteria (age $<1$ year, spring to winter seasons of collection, PCR assay) for Astrovirus distribution and occurrence in Iraq community. In the subsequent step of detection, out of the RTqPCR positive samples, conventional PCR method introduced isolate with high viral load $(2.5 \%)$ of 39 patients for astrovirus with 719 bp., which was recorded with the lowest cut value $(17 \mathrm{Ct})$ and the Tm (76.1) in RT-qPCR. That's as may belong to the high sensitivity of RT-qPCR other than the RT-qPCR as what mentioned with Royuela et al., 2006, study (30) in which RT-qPCR identified IUs down to a $10^{-6}$ dilution, whereas the RT-qPCR identified down to IUs $10^{-2}$ dilution. However the percentage of RT-qPCR astrovirus positive results agreed with Thewiny, et al 2014 study (33) that detected $2.6 \%$ astrovirus from 200 infected patients. Notably, in this study the gastroenteritis infection showed a higher frequency in isolates with co-infection models (52.9\% with EVs and $30.7 \%$ with Rotavirus) 
other than with the single infection models (6.1\% with EVs and $20.5 \%$ with Rotavirus). These results have agreed with local study (6) and many global studies $(11,22,34)$ which revealed that the gastroenteritis may not only come from single viral infection, but also from co- viral infection with some enteric viruses, such as enterovirus, adenovirus, Rotavirus, norovirus and Astrovirus. Moreover, the high frequency of the co-infection model for the astrovirus with rotavirus and enterovirus have proved the efficacy of the real time PCR as an efficient alternative method in the detection of astrovirus from these dual gastroenteritis infections. In this study, there is a significant incidence of astrovirus in males other than females, in the enterovirus group, the result reversed in the rotavirus group but with no significant difference. However, these outcomes matched with several studies that the infected males' percentage was higher than females $(6,19,22)$. The percentage of coinfection model to the Astrovirus with Enterovirus and Rotavirus was higher in the vaccinated children with OPV and RV for poliovirus and Rotavirus respectively, other than the single infection. That's explained by Taniuchi et al., 2016 study (32) in which the previous infection with enteric viruses decrease the immunization of the immune system of the vaccinated children against the OPV and RV vaccines which make the child would easily infect with rotavirus and Sabinepolio virus

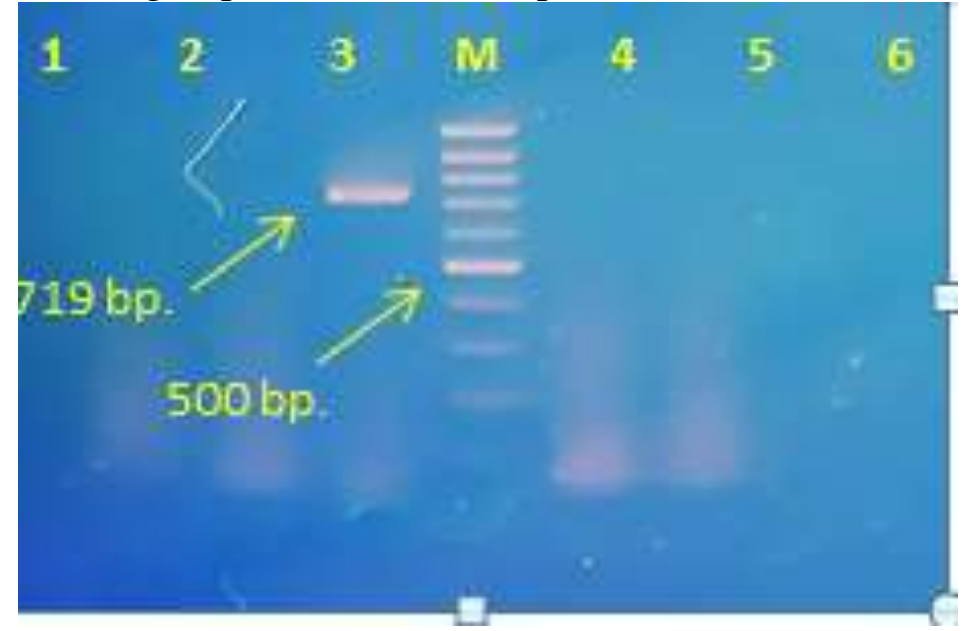

Figure 3. Amplification of an ORF1b gene of Astovirus positive sample in lane 3 by using RTPCR. Amplicons size was with 719 bp. Lanes 1,2, 4 and 5 for negative, while the lane 6 for control. The amplicons were run on agarose gel $1 \%$ and visualized with Transilluminator, $M$ : Marker (ladder) ranged 100-1000 bp

Astrovirus serotypes sequencing

Overall, the nucleotide sequence analysis of the ORFb1 region of the Astrovirus isolate was successfully done by amplifying the RTPCR product (719 bp). The Iraqillocal Astrovirus isolate in this study was analyzed and compared with the reference strains available in the Genbank database at NCBI (Fig. 4). The Basic Local Alignment Search Tool (BLAST) gave a sequencing result seemed $100 \%$ compatible with reference ORFb1 gene and the isolate types as MamAstrovirus- 1 (AstV-1). MamAstrovirus1 MK948878 is the first local isolate recorded in the Genbank. The HAstV reference strains sequences included in this study were obtained from GenBank under following accession numbers: MamAstrovirus 1 MH446382.1
Russia, MK430063.1 South Korea, KY744141.1 Italy, KY271945.1 USA, JQ898572.1 Thailand, KM981712.1 China, HQ398856.2 Hungary, AB009984.1 Japan.

The gender distribution of the Astrovirus in the Rotavirus and Enterovirus suspected groups

According the RT-qPCR results, There is no significant difference showed in the frequency of Astrovirus between gender $\left(\mathrm{X}^{2}=0.93\right.$; $\mathrm{P}>$ 0.05) in the Enterovirus group, although the males showed a high frequency than females; with 22 astrovirus infections in total, 3 infected with Astrovirus- Sabine- poliovirus co- infected and 17 males with AstrovirusNPEVs co-infection (20 total co-infection), and 2 males infected with single infection, While only 7 females showed Astrovirus 
infection as 1 with single infection and 6 with co-infection (1 with Sabine- polio and 5 with NPEVs). The model with Rotavirus group is dissimilar, in which Astrovirus distribution in female 9 positive astrovirus total infections, 5 were co-infected and 4 were suffering from a single infection for Astrovirus while the total infection among males was 8 samples, 6 with co-infection and 2 with single infection that showed non significant difference $\left(\mathrm{X}^{2}=0.87\right.$; $\mathrm{P}>0.05)$. Noticeably, the co-infection model between Rotavirus and EVs was significant A. Phylogenetic tree and higher than the single infection one in all groups and both genders $\left(\mathrm{X}^{2}=4.2 ; \mathrm{P}<0.05\right)$

The frequency of astrovirus in the age group of the rotavirus suspected group

The statistical analysis of the RT-qPCR results, revealed that there is no significant difference in the Astrovirus distribution among the age groups $\left(\mathrm{X}^{2}=2.13 ; \mathrm{P}>0.05\right)$, in spite of the $61.54 \%$ of the rotavirus infections and $47.06 \%$ of the Astrovirus positive samples belonging to children under one year of age (Table-2).

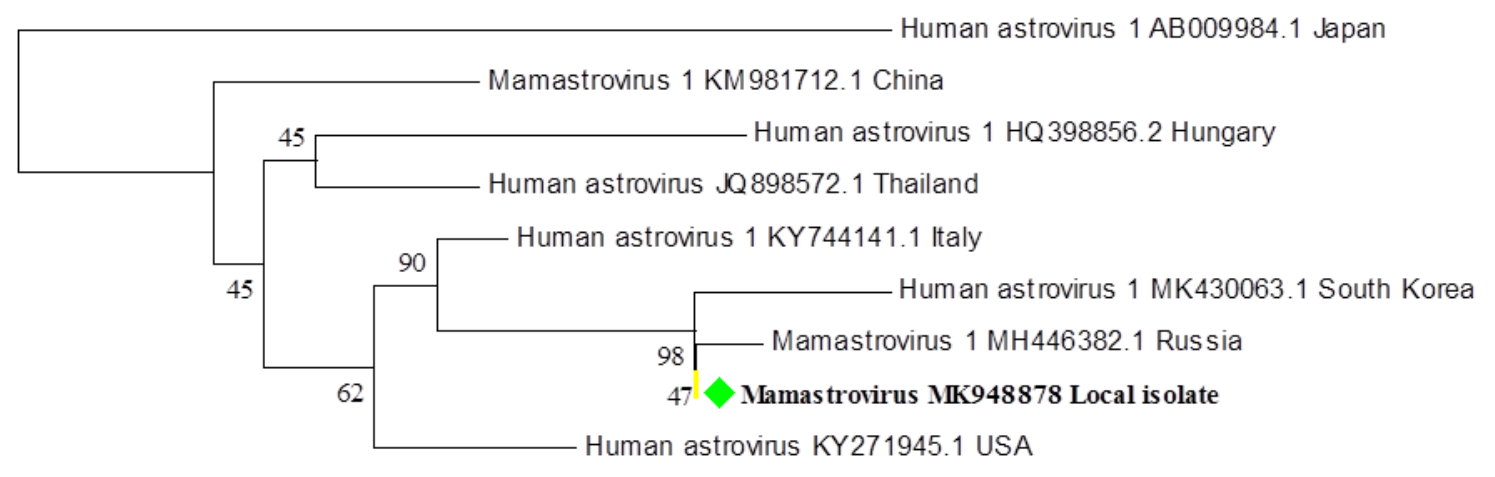

0.005

\section{B. Sequence Identity Matrix}

\begin{tabular}{|c|c|c|c|c|c|c|c|c|}
\hline MamAstrovirus $1 \mathrm{MH} 446382.1$ Russia & ID & & & & & & & \\
\hline Human Astrovirus 1 MK430063.1 South Korea & 0.988 & ID & & & & & & \\
\hline Human Astrovirus $1 \mathrm{KY} 744141.1$ Italy & 0.990 & 0.981 & ID & & & & & \\
\hline Human Astrovirus KY271945.1 USA & 0.985 & 0.976 & 0.991 & ID & & & & \\
\hline Human Astrovirus JQ898572.1 Thailand & 0.983 & 0.975 & 0.990 & 0.985 & ID & & & \\
\hline MamAstrovirus 1 KM981712.1 China & 0.980 & 0.971 & 0.986 & 0.985 & 0.986 & ID & & \\
\hline Human Astrovirus 1 HQ398856.2 Hungary & 0.975 & 0.968 & 0.981 & 0.980 & 0.985 & 0.978 & ID & \\
\hline Human Astrovirus 1 AB009984.1 Japan & 0.956 & 0.948 & 0.961 & 0.963 & 0.965 & 0.965 & 0.960 & ID \\
\hline MamAstrovirus MK948878 Local isolate & 0.998 & 0.990 & 0.991 & 0.986 & 0.985 & 0.981 & 0.976 & 0.958 \\
\hline
\end{tabular}

Figure 4. (A): Phylogenetic tree analyses of nucleotide sequences of ORFb1 of astrovirus strain detected in Iraq, Baghdad. The Iraqi strain was indicated with a symbol. The nucleotide sequence of ORFb1 of this strain was deposited in NCBI under submission number: MK948878. (B): the sequence similarity matrix, which showed the percentages of the identity to the local isolates with the other reference strains.

Table 2. Distribution of astrovirus and rotavirus infections among age groups.

\begin{tabular}{|lcc|}
\hline Age group/years & Rotavirus no. $(\%)$ & Astrovirus no. $(\%)$ \\
\hline$<1$ & $16(61.54 \%)$ & $8(47.06 \%)$ \\
$1-2$ & $9(34.61)$ & $6(35.19 \%)$ \\
$2-3$ & $1(3.84 \%)$ & $3(17.65 \%)$ \\
Total & 26 & 17 \\
\hline
\end{tabular}


Generally speaking, Ast $\mathrm{V}-1$ is the most frequently isolated type worldwide (13), in this study the sequenced strain has typed as AstV-1 serotype in a patient with a diarrheal infection aged 7 months old and this matched with Guix et al., 2002 study (18) which demonstrated that most infections with AstV-1 and AstV-3 occurred in children younger than 2 years old. As a result of its international distribution, a phylogenetic tree was established for the local strain to display its evolutionary relationship with other global stains. The tree mirrored this distribution in which the local strain presented a high relatedness with $98-99 \%$ identical to the reference strains that isolated from different continents, as Europe (Russia, Italy, Hungary), Asia (China, South Korea, Thailand, Japan) and North America (USA). The most related strain was from Russia that grouped with the Iraqi strain under the same cluster with $99 \%$ identity. Method of RTqPCR based on SYBR Green showed the rapid and efficient detection of astrovirus with few copies number. This allows to be used for the diagnosis of AstV along with other gastroenteritis viruses in a multiplex assay to reduce processing time. Subsequent applied nested PCR to overcome low viral load.

\section{REFERENCES}

1. Abad, F.X., C. Villena, S. Guix, S.Caballero, R.M. Pinto and A. Bosch. 2001. Potential role of fomites in the vehicular transmission of human astroviruses. Appl. Environ. Microbiol. 67:3904-3907

2. Abbas M.R. and S. M. K. Saadedin. 2018. Quantitative detection of CAMV- $35 \mathrm{~S}$ promoter and T-NOS terminator in genetic modified tomato from Iraqi markets. Iraqi $\mathbf{J}$ of Agricultural Sciences. 49(5): 309-381.

3. Ahmed A.I. and Sh.M. Odisho. 2018. Isolation identification and pathotyping of Newcastle disease viruses from naturally infected chickens in Iraqi Kurdistan region. Iraqi J of Agricultural Sciences. 49 (1): 132141

4. Ahmed, S.F., P.J. Sebeny, J.D. Klena, G. Pimentel, A. Mansour, A.M. Naguib, J. Bruton, , S.Y. Young, L.R. Holtz, and D. Wang. 2011. Novel astroviruses in children, Egypt. Emerg infect dis. 17(12): 2391
5. Al-Fatlawi M.S.H. and M.A.A. Al-Fatlawi. 2019. Molecular and phylogenetic study of Theileria SPP isolated from ticks in ALDiwaniyah city, Iraq. Iraqi $\mathbf{J}$ of Agricultural Sciences. 50(1): 574-574

6. Ali, S. H. M., G. I. A. Al-Wadi, B. A. G. Yassin, M. K. W. Al-Janabi, M. F. Al-Timimi and H.S. Hussein. 2016. Prevalence of rotavirus, adenovirus, astrovirus and enteroviruses involved in acute infantile and childhood gastroenteritis in Baghdad: a Stoolbased antigenic study. Inter. J. of Info Res and Rev. 3(6): 2467-2475

7. AL-Sadawi, A. A., M. Al-Ammar, and N.S. Tuwaij. 2017. Viral agent that causing diarrhoea among children in Al-Najaf province, Iraq. World J. Pharma. Res, 6(8): 111

8. Al-Shuwaikh, A. M. A. 2016. Frequency of rotavirus, adenovirus and astrovirus among patients with acute diarrhea by chromatographic immunoassay and enzyme linked immunosorbent assay. J. of Biotechnology Research Center, 10(2): 58-64 9. Appleton, H. and P.G. Higgins. 1975. Viruses and gastroenteritis in infants (letter). Lancet i: 1297

10. Bergallo, M., I. Galliano, V. Daprà, M. Rassu, P. Montanari and P.A. Tovo. 2018. Molecular detection of human astrovirus in children with gastroenteritis, Northern Italy. The Ped. Infect. Dis. J., 37(8): 738-742 11. Biscaro, V., G. Piccinelli, F. Gargiulo, G. Ianiro, A. Caruso, F. Caccuri and M.A. De Francesco. 2018. Detection and molecular characterization of enteric viruses in children with acute gastroenteritis in Northern Italy. Infect, Gen and Evol. 60: 35-41

12. Bosch,A., M.R. Pinto and S. Guix, 2018. Human astroviruses. Clinic. Microbiol. Rev.,27 (4): 1048-1074

13. Chan-it, W., A. Thongprachum, S. Okitsu, M. Mizuguchi and H. Ushijima. 2010. Epidemiology and molecular characterization of sapovirus and astrovirus in Japan, 20082009. Jpn. J. Infect. Dis. 63:302-303

14. Dai, Y., Q. Xu, X. Wu, G. Hu, Y. Tang, J. Li, Q. Chen and J. Nie. 2010. Development of real-time and nested RT-PCR to detect astrovirus and one-year survey of astrovirus in 
Jiangmen City, China. Arch. Virol. 155: 977982

15. De Benedictis, P., S. Schultz-Cherry, A. Burnham and G. Cattoli. 2011. Astrovirus infections in humans and animals-Molecular biology, genetic diversity, and interspecies transmissions Infect. Genet. Evol., 11: 15291544

16. Dey, S. K., H. Ushijima, O. Phathammavong, W. Chanit, S. Okitsu, M. Mizuguchi and Y. Ota. 2010. Seasonal trend and serotype distribution of rotavirus infection in Japan, 1981-2008. Pediatr. Infect. Dis. J. 29:166- 167 .

17. Fadhil, H.Y. 2014. Detection for respiratory syncytial virus RNA among children with flu-like illness using molecular assay. Internat $\mathbf{J}$ of Current Research. 6 (1): 9455-9459

18. Guix, S., S. Caballero, C. Villena, R. Bartolome, C. Latorre, N. Rabella, M. Simo, A. Bosch and R.M. Pinto. 2002. Molecular epidemiology of astrovirus infection in Barcelona, Spain. J. Clin. Microbiol. 40:133139

19. Hussein, A. A., R.A. Hussein and M.J. Shaker. 2018. Enteric viruses co-infection with giardiasis among diarrheal children in Diyala Province-Iraq. J. Pu. and appl. Microbiol. 12 (2): 793-799

20. Jacobsen, S., M. Höhne, A.M. Marques, K. Beslmüller, C.T. Bock and S. Niendorf. 2018. Co-circulation of classic and novel astrovirus strains in patients with acute gastroenteritis in Germany. J. Infect. 76(5): 457-464

21. Jeong, H.S., A. Jeong and D.S. Cheon. 2012. Epidemiology of astrovirus infection in children. Korean. J. Pediatr. 55 (3): 77-82

22. Koh, H., S.Y. Baek, J. I. Shin, K.S. Chung and Y.M. Jee. 2008. Coinfection of viral agents in Korean children with acute watery diarrhea. J. Kor. Med. Sci., 23(6): 937-940

23. Le Cann P, S. Ranarijaona, S. Monpoeho, F. Le Guyader and V. Ferré. 2004. Quantification of human astroviruses in sewage using real-time RT-PCR. Res. Microbiol. 155: 11-15

24. Lee, R. M., J. Lessler, R.A. Lee, K.E. Rudolph, N.G. Reich, T.M. Perl and D.A. Cummings. 2013. Incubation periods of viral gastroenteritis: a systematic review. BMC infect. Dis.13(1): 446
25. Logan, C., J.J. O'Leary and N. O'Sullivan. 2007. Real-time reverse transcription PCR detection of norovirus, sapovirus and astrovirus as causative agents of acute viral gastroenteritis. J. Virol. Methods.146: 36-44 26. Maham, S., N. Marhamati, F. Fallah, R.S. Nia and F. Atashrazm. 2013. Epidemiology of astrovirus infection in young children hospitalized with gastroenteritis in Iran, over a period of seven years, using reverse Transcriptase-polymerase chain reaction (RTPCR). J. of Pub Heal and Epidemiol. 5(1):3742

27. Mitab, H. H. 2013. Comparison of multiplex real time PCR with ELISA for diagnosis of viral Gastroenteritis in children of Al-Muthana province. Almuth. J. Pu. Sci. 1(1). 28. Moser, L.A. and S. Schultz-Cherry. 2005. Pathogenesis of astrovirus infection. Viral Immunol. 18:4-10.

29. Pérot, P., M. Lecuit and M. Eloit. 2017. Astrovirus diagnostics. Viruses. 9 (10): 1-14.

30. Royuela, E., A. Negredo and A. SanchezFauquier. 2006. Development of a one step real-time RT-PCR method for sensitive detection of human astrovirus. J. Virol. Methods 133:14 -19.

31. Saleh, D.S., H.Y. Fadhil and F.G. AlHamdani. 2012. Screening for high-risk human papillomavirus by real-time PCR and its association with cytological abnormalities of Pap smears in Baghdad. International $\mathbf{J}$ of Microbiol. Research, 4(9): 332-335.

32. Taniuchi, M., J.A. Platts-Mills, S. Begum, M.J. Uddin, S.U. Sobuz, J. Liu and E.R. Houpt. 2016. Impact of enterovirus and other enteric pathogens on oral polio and rotavirus vaccine performance in Bangladeshi infants. Vaccine, 34(27): 3068-3075.

33. Thewiny, H. T., H.J. Hasony and B.D. Salman. 2014. Human astrovirus among hospitalized children under five years of age with acute diarrhea in basrah, Iraq. Med J. B. Uni. 32(2): 71-76

34. Tran, A., D. Talmud, B. Lejeune, N. Jovenin, F. Renois, C. Payan, N. Leveque and L. Andreoletti. 2010. Prevalence of rotavirus, adenovirus, norovirus, and astrovirus infections and coinfections among hospitalized children in northern France. J. Clin. Microbiol. 48(5): 1943-1946 
35. Tseng, W. C., F.T. Wu, C.A. Hsiung, W.C. Chang, H.S. Wu, C.Y. Wu, J.S. Lin, S.C. Yang, K.P. Hwang and Y.C. Huang. 2012. Astrovirus gastroenteritis in hospitalized children of less than 5 years of age in Taiwan, 2009. J. Microbiol. Immunol. Infect. 45(4):311-7

36. Wilhelmi de Cal, I., R.B. MohedanodelPozo and A. Sánchez- Fauquier. 2008. Rotavirus and other viruses causing acute childhood gastroenteritis. Enferm. Infec. Microbiol. Clin. Suppl. 13:61-5.
37. Yan, H., F. Yagyu, S. Okitsu, O. Nishio and H. Ushijima. 2003. Detection of norovirus (GI, GII), sapovirus and astrovirus in fecal samples using reverse transcription singleround multiplex PCR. J. Virol. Method 114: $37-44$

38. Zaraket, H., H. Abou-El-Hassan, K. Kreidieh, N. Soudani, Z. Ali, M. Hammadi and M. Rajab. 2017. Characterization of astrovirus-associated gastroenteritis in hospitalized children under five years of age. Infect, Gen and Evol. 53: 94-99.. 